\title{
THE INTER-COMPARISON OF AATSR AEROSOL OPTICAL DEPTH RETRIEVALS FROM VARIOUS ALGORITHMS
}

\author{
Yahui Che ${ }^{(1,3)}$, Yong Xue ${ }^{\left(1,2^{*}\right)}$, Hui Xu ${ }^{(1,3)}$, Romas Mikusauskas $^{(2)}$, Lu She $^{(1,3)}$ \\ ${ }^{1}$ Key Laboratory of Digital Earth Science, Institute of Remote Sensing and Digital Earth, Chinese \\ Academy of Sciences, Beijing 100094, China \\ ${ }^{2}$ Faculty of Life Sciences and Computing, London Metropolitan University, 166-220 Holloway Road, \\ London N7 8DB, UK \\ ${ }^{3}$ University of Chinese Academy of Sciences, Beijing 100049, China \\ \{Email: 15011546747@163.com,y.xue@londonmet.ac.uk\}
}

\begin{abstract}
The project aerosol-CCI as part of European Space Agency (ESA) Climate Change Initiative (CCI) has provided three aerosol retrieval algorithms for the Advanced Along-Track Scanning Radiometer (AATSR) aboard on ENVISAT. For the purpose of estimating different performance of these three algorithms in Asia, in this paper we compared the Aerosol Optical Depth (AOD) of L2 data $(10 \mathrm{~km} \times 10 \mathrm{~km})$ including FMI AATSR Dual-view ADV algorithm, the Oxford RAL Aerosol and Cloud retrieval (ORAC) algorithm and the Swansea University AATSR retrieval (SU) algorithm with the AErosol RObotic NETwork (AERONET) and the China Aerosol Remote Sensing Network (CARSNET) data separately. The result shows that the algorithms of ADV and SU have good performance on the retrieval of AOD, and the ORAC algorithm has relative lower precision than other two algorithms.
\end{abstract}

Index Terms-aerosol optical depth (AOD), validation, satellite remote sensing, AATSR

\section{INTRODUCTION}

Solid or liquid particles with radius varying from $100 \mathrm{~nm}$ to $100 \mu \mathrm{m}$ suspended in the atmosphere compose atmospheric aerosol. The source of atmospheric aerosols can be natural or not. Various types of aerosol change the Earth's radiation budget by both affecting radiation transfer directly and affecting cloud properties [1]. However, the average compositions vary with time, size, location and the bulk compositions of individual particles, leading to unavoidable uncertainties in measurements of spatial and temporal properties. [2]

Anthropogenic aerosol is the largest uncertainty in climate forcing constituent (IPCC, 2013), which calls for further work to improve all types of available observation [3]. Conventional ground-based observation can't be used to detect entire properties of aerosols. Since the launch of Landsat, satellite data have been used to retrieve properties and distribution of aerosol. The Advanced Along-Track Scanning Radiometer (AATSR) aboard on ENVISAT is using to observe the Earth by dual-view. The data of AATSR can be used to retrieve aerosol optical depth (AOD) both over land and ocean, which is an important merit in the characterization of aerosol properties [4].

Using AATSR data, several effective algorithms have been developed, including the FMI AATSR retrieval algorithm (ADV/ASV), the Oxford RAL Aerosol and Cloud retrieval (ORAC) and the Swansea University AATSR retrieval (SU). The ADV/ASV algorithm over land is based on the so-called $\mathrm{k}$ assumption, where the ratio $(\mathrm{k})$ of the ground reflectance for the two views is assumed to be independent of wavelength [7]. Using $1.61 \mu \mathrm{m}$ wavelength to compute the $\mathrm{k}$, ADV/ASV algorithm assumes that aerosols are negligible when compared to ground reflectance. The ORAC algorithm is based on an optimal estimation method [6] and the SU algorithm is based on iterative optimization of AOD and aerosol model subject to multiple constraints [3].

Ground-based sunphotometer has been used to take sun and sky measurement directly [10]. Both AERONET and CARSNET have high precision in observing AOD. In this paper, we evaluated performance of AATSR algorithm for AOD of L2 $(10 \mathrm{~km} \times 10 \mathrm{~km})$ aerosol products using the AERONET and the CARSNET data. In section 2, we give the introduction of main method and processing procedure briefly. The result is presented in section 3. The result analysis is presented in Section 4.

\section{METHOD}

\subsection{Validation}

AERONET or other ground-based network provides accurate measurements without influence of land surface reflection (Holben et al., 1998), compared with ground- 
based measurements is the basic method. AOD of L2 data sets were compared with AERONET/CARSNET data using scatter plots and linear-regression to the data. The comparisons were made for collocated satellite and AEROENT/CARSNET observations (Ichoku, 2002), i.e. AOD pixels were selected within a spatial extent of $+/-50$ $\mathrm{km}$ and a time range of $+/-30$ min from AERONET/CARSNET measurements.

\subsection{Statistics}

Several statistics are selected to estimate different performances:

(1) Mean bias error (MBE) and Mean absolute error (MAE) represent the degree of deviation satellite retrieved AOD and AERONET/CARSNET observed AOD.

(2).Correlation coefficient (CC) represents the linear relationship between AATSR AOD and ground-based observation.

(3) Root mean square error (RMSE) represents the average deviation of uncertainty in satellite-retrieved AOD.

$$
\begin{gathered}
M B E=\frac{1}{n} \sum_{i=1}^{n}\left(\tau_{\text {sat }, i}-\tau_{\text {aer }, i}\right) \\
M A E=\frac{1}{n} \sum_{i=1}^{n}\left|\left(\tau_{\text {sat }, i}-\tau_{\text {aer }, i}\right)\right| \\
C C=\frac{\sum_{i=1}^{n}\left(\tau_{\text {aer }, i}-\overline{\tau_{\text {aero }}}\right)\left(\tau_{\text {sat }, i}-\overline{\tau_{\text {sat }}}\right)}{\sqrt{\sum_{i=1}^{n}\left(\tau_{\text {aer }, i}-\overline{\tau_{\text {aero }}}\right)^{2} \sqrt{\sum_{i=1}^{n}\left(\tau_{\text {sat }, i}-\overline{\tau_{\text {sat }}}\right)^{2}}}} \\
R M S E=\sqrt{\frac{1}{n} \sum_{i=1}^{n}\left(\tau_{\text {sat }, i}-\tau_{\text {aero }, i}\right)^{2}}
\end{gathered}
$$

Where, $i$ means the number of each AOD pixel, $\tau_{\text {aer }, i}$ means the value of AERONET AOD for site $i$, $\tau_{\mathrm{sat}, i}$ means the corresponding satellite-retrieved AOD.

\section{DATA AND RESULTS}

\subsection{Study Area and Data}

The study area is in mainland China and a part of middle Asia, the spatial range as $35^{\circ}-150^{\circ} \mathrm{E}, 15^{\circ}-60^{\circ} \mathrm{N}$. The data we used are AATSR aerosol products 2008 over the study area. We selected AATSR L2 AOD, which has the resolution of $10 \mathrm{~km} \times 10 \mathrm{~km}$. The ancillary data are AERONET and CARSNET ground-based observed data.

The details of these three aerosol products are shown in table1.

\subsection{Results}

After preprocessing, we matched AATSR AOD with ground-based observed AOD using the method depicted above. The ORAC L2 product has largest coverage, which makes validation result with most collocation pairs, 323 pairs, 350 pairs with AERONET and CARSNET respectively. The ADV and SU L2 products have similar validated results with same amount of collocation pairs. The numbers of ADV validation pairs are 201, 115 with AERONET and CARSNET respectively. The SU has 200, 129 pairs respectively.

Table 1. Details of AATSR aerosol Products

\begin{tabular}{lllll}
\hline algorithm & version & sensor & $\begin{array}{l}\text { Main } \\
\text { parameters }\end{array}$ & $\begin{array}{l}\text { Resolution } \\
\text { coverage }\end{array}$ \\
\hline ADV/ASV & 1.42 & AATSR & AOD,ANG & $\begin{array}{l}10 \mathrm{~km}, 1^{\circ} \\
\text { global }\end{array}$ \\
\hline SU & 4.2 & AATSR & AOD,ANG & $\begin{array}{l}10 \mathrm{~km}, 1^{\circ} \\
\text { global }\end{array}$ \\
\hline ORAC & 2.02 & AATSR & $\begin{array}{l}\text { AOD, } \\
\text { aerosol } \\
\text { type }\end{array}$ & $\begin{array}{l}10 \mathrm{~km}, 1^{\circ} \\
\text { global }\end{array}$ \\
\hline
\end{tabular}

\section{RESULT ANALYSIS}

Comparing different statistics in table 2, we can see that the ADV L2 product and SU L2 product have same accuracy with high CC and low RMSE as fig.1 fig.4 show, however, fig. 5 and fig. 6 show that the performance of ORAC L2 product is not good as the other two products. Obviously, ORAC L2 product has the largest coverage at the cost of accuracy. Both ADV and SU L2 products have good performance on AOD retrieval over study area, mainly because these two aerosol products have strict quality control. That's why the ADV and SU L2 products have relative low coverage than ORAC L2 product.

Table 2. Validation results: statistics

\begin{tabular}{cllllll}
\hline \multirow{2}{*}{ SU } & & $\mathrm{N}$ & MBE & MAE & CC & RMSE \\
\hline \multirow{2}{*}{ ADV } & AERONET & 200 & 0.004 & 0.089 & 0.855 & 0.120 \\
& CARSNET & 129 & 0.091 & 0.102 & 0.880 & 0.117 \\
\hline \multirow{2}{*}{ ORAC } & AERONET & 201 & 0.062 & 0.090 & 0.878 & 0.100 \\
& CARSNET & 115 & 0.153 & 0.158 & 0.784 & 0.130 \\
\hline \multirow{2}{*}{ AERONET } & 323 & -0.041 & 0.146 & 0.568 & 0.250 \\
& CARSNET & 350 & 0.026 & 0.201 & 0.647 & 0.334 \\
\hline
\end{tabular}

\section{CONCLUSION}

These three AATSR aerosol products provided by aerosolCCI have different performance in study area. Even though the statistics and scatterplots show ORAC product has low accuracy, we can't determine which product has best performance in Asia.

For the AOD retrieval on the base of satellite, the coverage and accuracy are competing. Therefore, when estimating different algorithms' performance on AOD retrieval, we need take both their coverage and accuracy into account. 


\section{ACKNOWLEDGMENTS}

The data for validation come for AERONET and CARSNET. We thank the PIs and their staff for establishing and maintaining these important data used in this investigation. This work was supported in part by EU/FP7 MarcPolo project (Grant Agreement Number 606953) and Aerosol_cci project (ESA-ESRIN project AO/1-6207/09/ILG)

\section{REFERENCES}

[1] U.S. Climate Change Science Program, Atmospheric Aerosol Properties and Climate Impacts, January 2009.

[2] Peter H. McMurry, "A review of atmospheric aerosol measurements", Atmospheric Environment, vol. 34, pp. 1959-1999, September 1999.

[3] T. Holzer-Popp, G. de Leeuw, J. Griesfeller, D. Martynenko, L. Kl"user, S. Bevan8, W. Davies, F. Ducos, J. L. Deuz'e7, R. G. Graigner, A. Hecke, W. von HoyningenH"une, P. Kolmonen, P. Litvinov, P. North, C. A. Poulsen, D. Ramon, R. Siddans, L. Sogacheva, D. Tanre, G. E. Thomas, M. Vountas, J. Descloitres, J. Griesfeller, S. Kinne, M. Schulz, and S. Pinnock, "Aerosol retrieval experiments in the ESA Aerosol cci project", Atmospheric Measurement Technique, pp. 1919-2013, August 2013.

[4] B. Adhikary, S. Kulkarni, A. Dallura, Y. Tang, T. Chai, L.R. Leung, Y. Qian, C. E. Chung, V. Ramanathan, and G. R. Carmichael, "A regional scale chemical transport modeling of Asian aerosols with data assimilation of AOD observations using optimal interpolation technique",

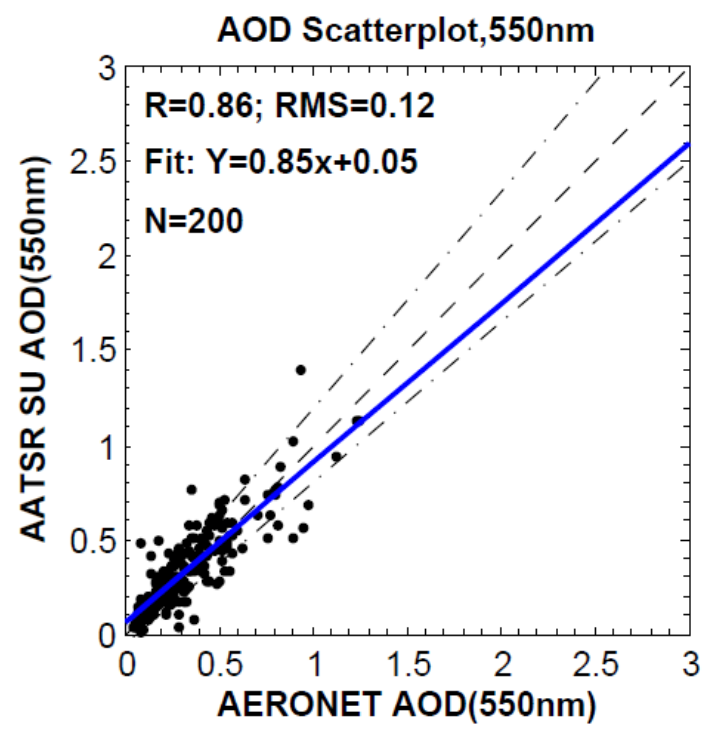

Fig. 1. Comparison between AATSR SU AOD and AERONET data in 2008
Atmospheric Environment, Vol. 42, pp.8600-8615, December 2008.

[5] Roland J. Flowerdew and Joanna D. Haigh, "Retrieval of aerosol optical thickness over land using the ATSR-2 Dual-Look Satellite Radiometer", Geophysical Research Letters, Vol. 23. Issue 4, pp. 351-354, 15 February 1996.

[6] Gareth E. Thomas, Elisa Carboni, Andrew M. Sayer, Caroline A. Poulsen, Richard Siddans and Roy G. Grainger, "Oxford-RAL Aerosol and Cloud (ORAC): aerosol retrievals from satellite radiometers" Satellite Aerosol Remote Sensing over Land Springer Praxis Books, pp. 193225, 2009.

[7] Kolmonen P, Sogacheva L, de Leeuw "G. Algorithm Theoretical Basis Document (ATBD) AATSR Dual View Algorithm (ADV), version 1.0". Document reference: Aerosol_cci_FMI_v1.0.doc, 2011.

[8] Charles Ichoku, D. Allen Chu, Shana Mattoo, Yoram J. Kaufman,Lorraine A. Remer, Didier Tanre', Ilya Slutsker and Brent N. Holben, "A spatio-temporal approach for global validation and analysis of MODIS aerosol products", Geophysical Research Letters, vol. 29, Issue 12, pp. MOD1-1-MOD1-4, 2002.

[9] D. A. Chu, Y. J. Kaufman, C. Ichoku, L. A. Remer, D. Tanre' and B. N Holben, "Validation of MODIS aerosol optical depth retrieval over land", Geophysical Research Letter, vol. 29, Issue 12, pp. MOD2-1-MOD2-4, 2002.

[10] B. N. Holben, T. F. Eck, I. Slutsker, D. Tanre',J. P. Buis,k A. Setzer, E. Vermote, J. A. Reagan, Y. J. Kaufman, T. Nakajima, F. Lavenu, I. Jankowiak, and A. Smirnov, "AERONET-A Federated Instrument Network and Data Archive for Aerosol Characterization", Rem. Sens. Environ., 66, 1 - 16, 1998.

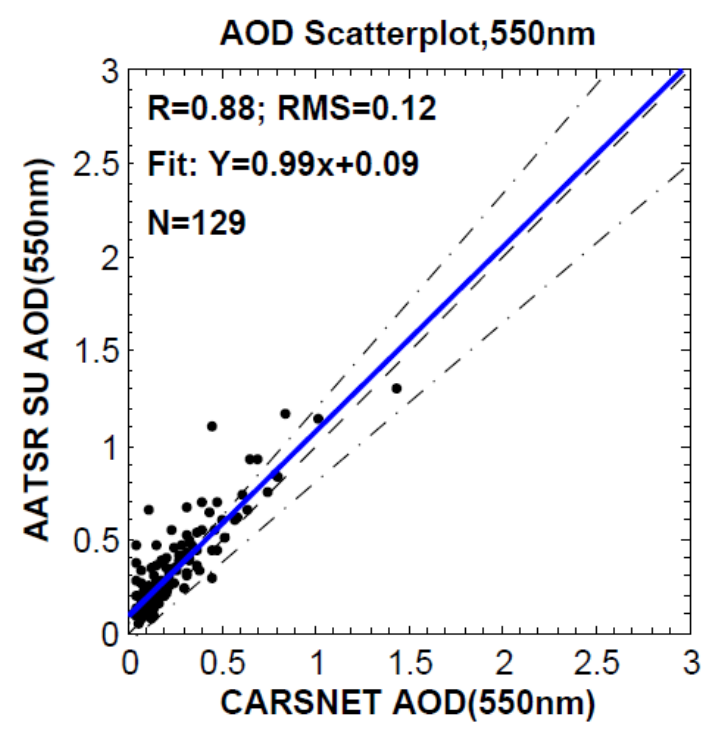

Fig.2. Comparison between AATSR SU AOD and CARSNET data in 2008 


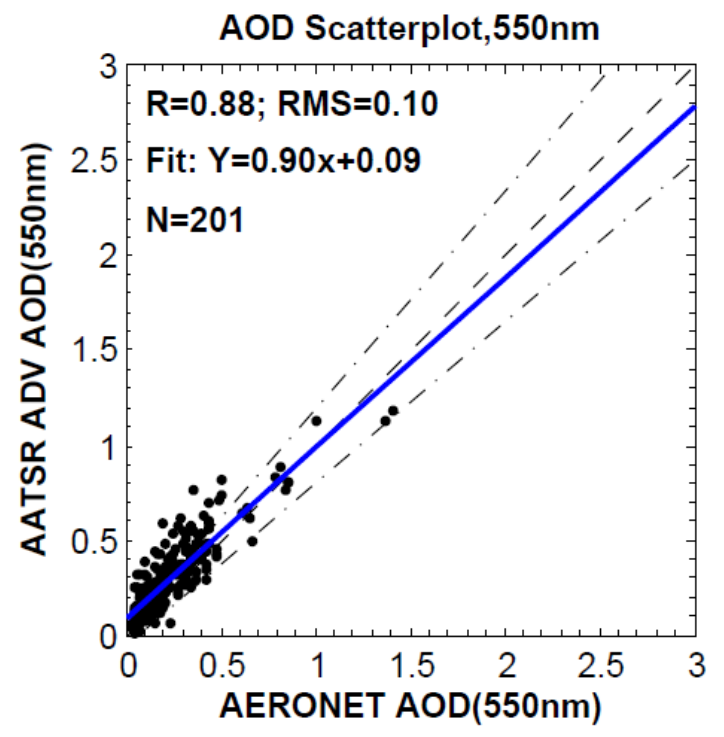

Fig.3. Comparison between AATSR ADV AOD and AERONET data in 2008

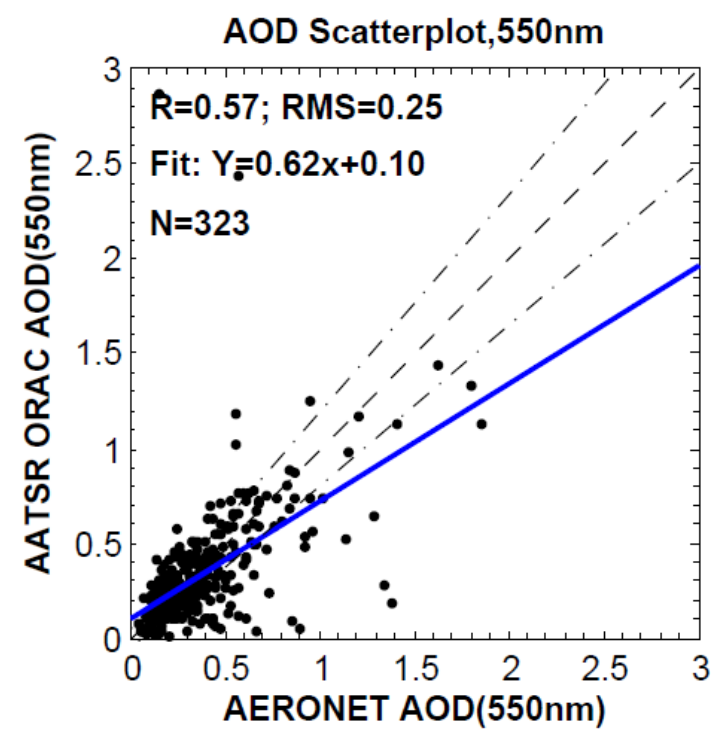

Fig.5. Comparison between AATSR ORAC AOD and AERONET data in 2008

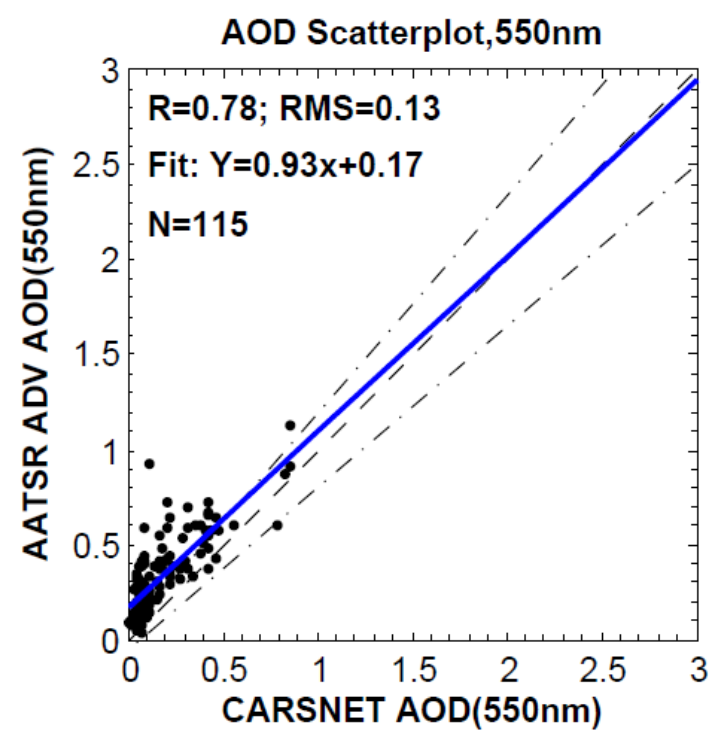

Fig.4. Comparison between AATSR ADV AOD and CARSNET data in 2008

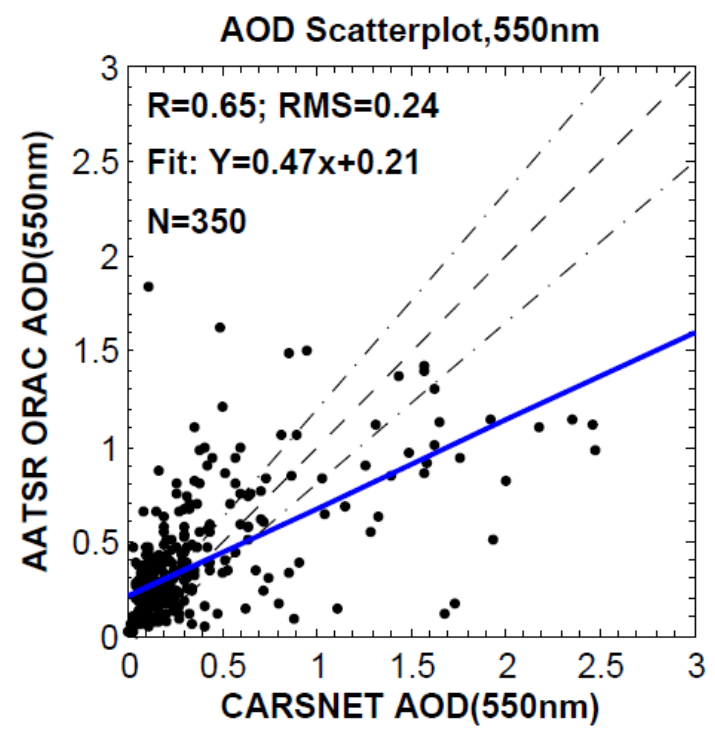

Fig.6. Comparison between AATSR ORAC AOD and CARSNET data in 2008 